Teli, M. (2019). Family Empowerment Model for Type 2 DM Management: Integration of Self care Model by Orem and Family Centered Nursing by Friedman in Sikumana Health Center-

Kupang. JURNAL INFO KESEHATAN, 17(1), 75-87. https://doi.org/10.31965/infokes.Vol17.Iss1.261

Jurnal Info Kesehatan

Vol 17, No.1, Juni 2019, pp. 75-87

P-ISSN 0216-504X, E-ISSN 2620-536X

Journal DOI: https://doi.org/10.31965/infokes

Website: http://jurnal.poltekeskupang.ac.id/index.php/infokes

RES EA R C H

Open Access

\title{
Family Empowerment Model for Type 2 DM Management: Integration of Self care Model by Orem and Family Centered Nursing by Friedman in Sikumana Health Center-Kupang
}

\author{
Margarteha Teli \\ Jurusan Keperawatan Kupang, Poltekkes Kemenkes Kupang \\ Email: margarethateli@gmail.com
}

\begin{abstract}
Abstrak
Background. The management of Diabetes which is very complex needs full support from the family. The family has a vital role in management type 2 diabetes at home involving diabetes diet, diabetes medication management, exercise, and also visit health care services for checking blood glucose and diabetes discussion session. Unfortunately, the family is rarely Involved in the health education session. The research aimed to identify the effect of family empowerment models: Integrated self-care model by Orem and Family-Centered Nursing by Friedman in type 2 DM management in Sikumana Health Center of Kupang. Methods. The research design was pra-experimental design with "One Group Pretest Posttest approach. The population of this study was 30 family members with type $2 \mathrm{DM}$. The data was collected by using questionnaires to measure the family members' ability to know type $2 \mathrm{DM}$, to make a proper decision, to take care of family members in term of diabetes diet management and to use health care services. Wilcoxon signed-Rank Test is used to figure out the effect of family empowerment model to conduct five family health function. Results. The study showed that the model improved the five health function performance by family members. While Wilcoxon signed-rank test also showed there was a significant effect of family empowerment model in terms of the family's ability to recognize type 2 $\mathrm{DM}(\mathrm{p}=0.0001)$, to make a right decision to take care the patient $(\mathrm{p}=0.0005)$. Moreover, the models have also improved the family ability to diabetes diet management $(p=0,046)$, to motivate the patient to do regular exercise and to uses the health care facilities $(p=0,014$ and 0,025 respectively). Conclusions. The study recommended to actively involve the family members to take care of type 2 diabetes patient due to it affects the entire family. The family members should be well informed so that they can improve the quality of family health.

Kata Kunci: Type 2 DM, Self Care-Orem Model, Family Centered Nursing-Friedman, Family Health Function.
\end{abstract}




\footnotetext{
*Correspondence: margarethateli@gmail.com

Present Address: Malang, Indonesia

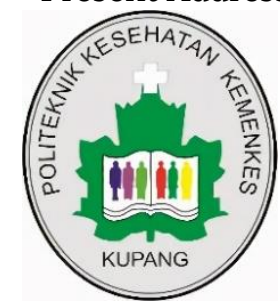

(CThe Author(s) 2018. This article is distributed under the terms of the Creative Commons Attribution 4.0 International License (http://creativecommons.org/licenses/by/4.0/), which permits unrestricted use, distribution, and reproduction in any medium, provided you give appropriate credit to the original author(s) and the source, provide a link to the Creative Commons license, and indicate if changes were made. The Creative Commons Public Domain Dedication waiver (http://creativecommons.org/publicdomain/zero/1.0/) applies to the data made available in this article, unless otherwise stated.
}

\section{INTRODUCTION}

Diabetes Mellitus is well known as a disease which affects all family members. When a person diagnozed with type II $\mathrm{DM}$, they are told about the care needed. The treatment needed includes diabetes medication, diabetes diet, and regular exercises. Most doctors and nurses merely focus on type II DM Patients. Patients are often asked to check daily blood glucose with a glucometer. Some other patients were given brochures or pamphlets, so that they can read, learn and practice the advices. Unfortunately, in the most cases, family members were not really involved in this steps. Family members are rarely involved in education session, eventhough family members are an important component in diabetes care management.

According to the DM control and prevention center (2008), 23.6\% children and adults in the United States or $7.8 \%$ of the population suffered from diabetes. However, only about $17.9 \%$ of millions of people already know that they are affected by Diabetes, and there are still around 5.7 million other people who do not realize that they are affected by diabetes. Based on The American Heart Association (2008), it is about $7,3 \%$ of people with Diabetes get access to treatment goals according to blood glucose, blood pressure and blood cholesterol levels. $65 \%$ of people with DM die from heart attacks and strokes.

World Health Organization (WHO) reported (2007) that Indonesia ranked at fourth Position in contributing to Diabetes Mellitus in the world after India, China and the United States. The prevalence of Diabetes Mellitus is about $8.6 \%$ of the entire Indonesian population, while according 
to International Diabetes Federation (IDF) 2009 estimated the number of people with diabetes mellitus dramatically increased from 7.0 million in 2009 to 12.0 million in 2030. Based on WHO survey statistics, the number of DM in Indonesia is 17 million people (8.6\%) of the population. In 2006 the number of DM patients in Indonesia reached 14 million people. Unfortunately, only $50 \%$ of patients are aware that they have DM, and only $30 \%$ of them take medication regularly. Mean while Basic Health Research (2017) showed the prevalence of diabetes mellitus in NTT was $1.8 \%$. Report from Sikumana Public Health center showed that there were 50 patients, but there were still other DM patients who were not aware of DM.

Diabetes patients learn some facts of diabetes, but they do not always inform the family members about what the doctor said. In most cases, family members do other different things with doctor's advice. Even, some of them think this is not my problem. If this condition happens, it will increase the prevalence of complication which then can reduce the quality of life. DM is a family problem. Family should be involved in taking care of the family.

Family are supposed to involve in diabetes management that includes medication, diet and regular exercise (Mahdiana, 2010). Treatment of diabetes mellitus includes oral hypoglycemic agents (OHAs) or insulin therapy. DM patients should be able to follow diet guidelines such as the amount of food needed, the type of food recommended and meal schedules for patients with diabetes mellitus. Exercises is also very important for the DM Patients. The patients should be able to follow FIIT principle namely the frequency, intensity, time and type of exercise at least 5 times a week for 30 minutes each time.

Management of diabetes mellitus can be achieved when the family provided enough support in order to achieve the patient level of independence. The form of family support are measuring the amount of calory, providing recommended food for 
the patients, encouraging patients to regularly take medicine, controlling blood glucose, and remaning the patients to do exercise. Lack of family support, will decrease the patient's of independence level to control diet, medicine and exercise. Those condition lead to unconrolled blood glucose and complication of Tipe 2 Diabetes (Ananta, 2009). Management of diabetes mellitus is strongly influenced by the presence of roles and support from the family. Setiadi (2007) stated that in term of taking care the family member who suffered from tipe 2 Diabetes, family should be able to recognize the tipe $2 \mathrm{DM}$; to make right decision for the patients, to provide care to family members, to maintain a home atmosphere that benefits the health and personality development of family members, and to use the health care facilities for diabetes care.

Supportive educative concepts of self Care Theory by Orem is focused to provide health education for patient and family. If informations are unclear, patients and family being misunderstanding which will cause poor self-care practice and lead to increase the prevalence of diabetes complications (Than, Ong, Tan \& How, 2004 in Svartholm and Nylander, 2010). Prevoius Research showed that a lifestyle approach can minimize the incidence of type 2 DM. A study conducted in UK showed that the intervention in lifestyle group more effective to reduce the incidence of DM than the intervention in medication group.

Family play an important role to support the healthy life style practice of the type 2 DM. Friedman (2003) stated that the family is a basic unit that provide care for family member who suffered from a disease. Family is a care center for the family and resources of care. Type 2 DM patients generally practice unhealthy eating habits. Therefore they need family support to manage diet, exercise ad changing their lifestyle. The study aimed to identify the effectiveness of Family

Empowerment model: Integration of Application of Self Care Model and Family Centered Nursing for type 2 DM management.

\section{MATERIAL AND METHODS}


Pra-experimental design with one group pretest-postest design was used in this study. The process was starting with the asessment of five family health tasks (knowing the family health problems, making the right decision, taking care of family health, managing healthy environment and using health facilities), determine the nursing diagnosis, develop nursing strategies, implementation and evaluation. Family Empowerment Model used during the implementation process. While the last process was measuring the five family health tasks (after implementation) to evaluate the effectiveness of the implemented model.

\section{Population and Samples}

The population in this study were all family in which one of them were diagnozed with type 2 DM. The sample was counted to 30 family of Type 2 DM Patients who visited Puskesmas Sikumana. The assessment is carried out on one family member with the criteria: having a kinship relationship with a DM patient, Staying at home and doing related treatments to prepare meals and other care arrangements. The samples taken were 30 people. Data were collected using a questionnaire containing multiple choice questions to see the ability of family to recognize Type $2 \mathrm{DM}$, to make an appropriate decision, to take care the family member with type 2 $\mathrm{DM}$, to manage the environment and to use the health facilities. The instrument used is modified from family APGAR of Type 2 DM including healthy diet, exercise, foot care, medication and blood sugar control.

\section{Statistical Analyses}

Wilcoxon Signed-Rank test is used to determine the effectiveness of Family Empowerment Model: Integration of Self Care Model and Family Centered Nursing - Friedman in type 2 DM management at Sikumana Health Center in Kupang City.

\section{RESULTS}

A total of 30 family with one member was diagnozed by Diabetes 
mellitus. Most of responden are the age are child. The date also showed that $50 \%$ of 31-40 years old $(43,4 \%)$. Most of them of patient being diagnozed of type $2 \mathrm{DM}$ graduated from the university; counted by 2-5 years.

$53,3 \%, 40 \%$ of them are wifehose, $36,7 \%$

Table 1 Disribution of sociodemographic characteristics of the study population

\begin{tabular}{|c|c|c|c|}
\hline No. & Characteristics & $\mathbf{N}$ & $\%$ \\
\hline \multirow[t]{6}{*}{1} & Age & & \\
\hline & - $21-30$ years & 2 & 6.7 \\
\hline & - 31-40 years old & 13 & 43.3 \\
\hline & - $\quad 41-50$ years & 5 & 16.7 \\
\hline & - 51-60 years old & 7 & 23.3 \\
\hline & - $>60$ years old & 3 & 10 \\
\hline \multirow[t]{5}{*}{2} & Education & & \\
\hline & - Elementary school & 1 & 3.3 \\
\hline & - Junior high school & 2 & 6.7 \\
\hline & - High school & 11 & 36.7 \\
\hline & - Diploma, bachelor and higher & 16 & 53.3 \\
\hline \multirow[t]{5}{*}{3} & Relation to the patients & & \\
\hline & - Wife & 12 & 40 \\
\hline & - Husband & 6 & 20 \\
\hline & - Child & 11 & 36.7 \\
\hline & - Other family in the house & 1 & 33.3 \\
\hline \multirow[t]{5}{*}{4} & $\begin{array}{l}\text { Length of being Diagnozed with } \\
\text { Type } 2 \text { DM }\end{array}$ & & \\
\hline & - $0-1$ years & 5 & 16.7 \\
\hline & - $2-5$ years & 15 & 50 \\
\hline & - 6-10 years & 8 & 26.7 \\
\hline & $-\quad>10$ years & 2 & 6.7 \\
\hline
\end{tabular}

Table 2 The ability of family to recognize diabetes mellitus before and after the the impelemtation of family Empowerment Model: Integration of self Care Model by Orem and Family Centered nursing by Friedman.

\begin{tabular}{ccccc}
\hline Level of family's ability & \multicolumn{2}{c}{ Before } & \multicolumn{2}{c}{ After } \\
\cline { 2 - 5 } to know type 2 DM & $\mathbf{N}$ & $\mathbf{\%}$ & $\mathbf{N}$ & $\mathbf{\%}$ \\
\hline Poor & 0 & 0 & 0 & 0 \\
\hline Moderate & 11 & 36.6 & 0 & 0 \\
\hline Good & 19 & 63.3 & 30 & 100 \\
\hline Total & 30 & 100 & 30 & 100 \\
\hline
\end{tabular}


Before application of model, we can see that $63,3 \%$ and 36,6 of the responden had good and moderate ability to recognize type 2 DM, repectivelly (Tabel 2) while, after the implementation of family empowerment model, the ability of family to know DM are all in the good category (30 people / 100\%).

Table 3 The ability of family to make right decisions to take type $2 \mathrm{DM}$ family members; before and after

\begin{tabular}{ccccc}
\hline $\begin{array}{c}\text { Level of family's ability } \\
\text { to make right decision of } \\
\text { taking care the type } 2 \\
\text { DM }\end{array}$ & N & Before & N & $\%$ \\
\hline Poor & 3 & 10 & 0 & 0 \\
\hline Moderate & 18 & 60 & 16 & 53.3 \\
\hline Good & 9 & 30 & 14 & 46.7 \\
\hline Total & 30 & 100 & 30 & 100 \\
\hline
\end{tabular}

Before the study conducted, most of family had moderate ability to make a good decision of taking care the type $2 \mathrm{DM}(60 \%)$, while after the implementation of empowerment model, no one family in poor category.

Table 4: Level of family's ability to manage Diabetes Diet (healthy eating plan) for the type $2 \mathrm{DM}$ : before and after

\begin{tabular}{ccccc}
\hline $\begin{array}{c}\text { Level of family's } \\
\text { ability to manage } \\
\begin{array}{c}\text { Diabetes Diet (healthy } \\
\text { eating plan) }\end{array}\end{array}$ & $\mathbf{N}$ & $\mathbf{\%}$ & $\mathbf{N}$ & $\mathbf{\%}$ \\
\cline { 2 - 5 } & 2 & 6.7 & 1 & 3.3 \\
\hline Poor & 10 & 33.3 & 8 & 26.7 \\
\hline Moderate & 18 & 60 & 21 & 70 \\
\hline Good & 30 & 100 & 30 & 100 \\
\hline Total & & & &
\end{tabular}

The data revealed that $60 \%$ of family had good ability to manage diabetes diet, $33,3 \%$ had moderate and 6,7\% who had poor category. After model implementation, it steady increased in all category. 
Table 5 Family's ability to support exercise and foot care for the type 2 DM: Before and after

\begin{tabular}{ccccc}
\hline $\begin{array}{c}\text { Level of family's ability } \\
\text { to support exercise and } \\
\text { foot care }\end{array}$ & \multicolumn{2}{c}{ Before } & \multicolumn{2}{c}{ After } \\
\cline { 2 - 5 } & $\mathbf{N}$ & $\mathbf{\%}$ & $\mathbf{N}$ & \% \\
\hline Poor & 11 & 36.7 & 8 & 26.7 \\
\hline Moderate & 11 & 36.7 & 11 & 36.7 \\
\hline Good & 8 & 26.7 & 11 & 36.7 \\
\hline Total & 30 & 100 & 30 & 100 \\
\hline
\end{tabular}

To support type $2 \mathrm{DM}$ patient to do exercise regularly and foot care is one of the main important famly health function. The study showed only $26,7 \%$ and $36,7 \%$ family who had good ability to support the patient; before and after.

Table 6: The level of family's ability to use health care services to keep healthy; Before and after

\begin{tabular}{ccccc}
\hline $\begin{array}{c}\text { Level of family's ability } \\
\text { to use health care } \\
\text { services for Type 2 DM }\end{array}$ & $\mathrm{N}$ & $\%$ & $\mathrm{~N}$ & $\%$ \\
\cline { 2 - 5 } & 10 & 33.3 & 6 & 20 \\
\hline Poor & 7 & 23.3 & 10 & 33.3 \\
\hline Moderate & 13 & 43.3 & 14 & 46.7 \\
\hline Good & 30 & 100 & 30 & 100 \\
\hline Total & & & &
\end{tabular}

The data showed that after implementation of the model; there was a steadily increased (46,7\% good category) in term of using helath facilities to check blood glucose and to get advice from nutrisionist.

\section{Statistical Analyses}

Table 7 Paired Samples t- test; analyze the effectiveness of family emporment model in type 2 DM management: before and after

\begin{tabular}{lc}
\hline & Asym. Sig. (2-tailed \\
\hline Level of family's ability to know type 2 DM & 0.001 \\
\hline $\begin{array}{l}\text { Level of family's ability to make right decision of } \\
\text { taking care the type 2 DM }\end{array}$ &, 005 \\
\hline $\begin{array}{l}\text { Level of family's ability to manage Diabetes Diet } \\
\text { (healthy eating plan) }\end{array}$ &, 046 \\
\hline
\end{tabular}




\begin{tabular}{ll}
\hline $\begin{array}{l}\text { Level of family's ability to support exercise and foot } \\
\text { care }\end{array}$ &, 014 \\
\hline $\begin{array}{l}\text { Level of family's ability to use health care services for } \\
\text { Type 2 DM }\end{array}$ &, 025 \\
\hline
\end{tabular}

Paired sample t-test showed a Present study showed that by application significant effect of the model to increase of empowerment model all have had the ability of family to perform five good knowledge about type $2 \mathrm{DM}(100 \%)$. health family function including to The length of time for being diagnozed by recognize the sign, symptomps and main type $2 \mathrm{DM}$ closely related to the level of causes of type $2 \mathrm{DM}$, to make a right diabetes understanding. Based on the decision, to manage dibetes diet, to study 19 family had been diagnozed for support exercise and foot care and also to use health care services $(p=0,001,0,005$, 0,046, 0014 and 0,025 respectively).

\section{DISCUSSION}

Indicators that showing the family knows health problems is related to the fact that family knows the understanding, sign and symptoms, main causes and family perception of a disease. When people/family have good undestanding on one problem, it has strong connection to have good behaviour in provide good care (Shepher, 2004). The study showed that on the assesment phase, only 16 family (63,3\%) had good Type 2 DM knowledge. While more than 1 year. If one of the family member have diagnozed, it will automatically encourage other family member to know more about that issue. Family empowerment model is focused on the effort to increase the family ability to perform better on five family function. A prevoius study about the effect of family terapy with family centered nursing approach showed a significant effect on the independence of type $2 \mathrm{DM}$ patient to do self-care (Paramitha, S. 2013).

Patient and family are supposed to be able to make a proper decision to have healthy behaviour. A proper decision especially in Diabetes management at 
home strongly influenced by the level of diabetes understanding. This study showed after application of the model, $53,3 \%$ family had moderate ability to make good decision and 46,7\% who had good ability to make good decision on diabetes management. To lead the family to make an appropiate decision, it really depend on the level of awareness of the diseases impact to health condition. The family should know that Diabetes cannot be healed but the patient can have a healthy life with Diabetes, the risk of complication decrease when the patient practice good dibetes management (Paramita.S, 2013). Family support will change people's behaviour and make people accept their condition. Family as a system need to support each other in term of implementation healthy lifestyle. Family who learn together will have positive perception and lead to change.

Diet magement plays important role to diabetes regulation especially blood glucose controlled. The study showed that the empowerment model increased the family's ability to take care the patient in term of provide healthy diet for patient (70\%). Family support needs to minimize the obstacle of diet management. Wen, L.K (2013) showed the main challenge to diet management is home environment factors and level of family knowlege. Home environment factors include family support diabetes diet. While level of knowledge will help patient to manage healthy diet including choosing the carbohydrate, protein and fat resources.

Diabetes diet management also influenced by social support. Previous research showed that family support become predictor to increase the ability to do slef care espeially diet management (Skinner, C.T, John M, Hampson, E.S., 2000). Family is well known as important componen to support yipe $2 \mathrm{DM}$ patient to have high quality of life and diabetes management. According to Joint Commission Standards for Disease or Condition-Specific Care, diabetes care that involve family member automatically increased patient compliance level for diabetes diet, exercise and medication. A recent study conducted by Glasglow dan Anderson, 2005 , recommended family support and social support group to diet 
management. Family is important part to emotionale suport of type $2 \mathrm{DM}$. Postive support which is coming from family will increase the acceptance of Type $2 \mathrm{DM}$ and lead to improve the self-care of DM. Therefore, involving all family members during education session of diabetic is very important. It can also eliminate barriers to self-care (Wen, L.K, Shepherd, M.D, 2004).

Physical exercise is one of the important management for controlling blood sugar levels in DM patients. Besides that it can also maintain or lose weight, and increase HDL cholesterol levels. Unfortunately, there are many reasons for being not active to exercise such as time, tired after work, back, knee and muscle pain, and uncomfortable environment to walk and lack of friends to exercise. These barriers can only be removed with the support of the family. The study illustrated there was a steadly increase in term of supporting the patient to do regular exercise and foot care. The study showed only $26,7 \%$ and $36,7 \%$ family who had good ability to support the patient; before and after.
One important intervention for this problem is through health education, counselling and discussion to all family members to reduce obesity and healthy diet. Family must be provided with information about the risks of obesity and inactivity, emphasizing the importance of exercise. Family are supposed to exercise together as scheduled such as as walking or doing daily activities at home. Physical activity must be used as a lifestyle. Wilcoxon test results showed a significant change of application empowerment model $(\mathrm{P}=$ 0.014 ) to increase the family's ability to support patient to exercise and foot care. One of the pillars of DM management is diabetes medicine to keep blood sugar levels as close to normal. After implementation of the model; there was a steadily increased (46,7\% good category) in term of using helath facilities to check blood glucose and to get advice from nutrisionist. DM patients are advised to always control blood sugar in laboratories, health centers or conducted by family at home. The family is highly expected to be 
a motivator of the the patient to use the health care facilities to check blood glucose, to discuss with nutrisionist and to take dibetes medicine regularly.

\section{CONCLUSION}

Based on the result of the present study, Family Empowerment Model for Type 2 DM Management: Integration of Self care Model by Orem and Family Centered Nursing by Friedman increase the five-family health function. By involving the family in the assesment, teaching diseases process, it will increase family participation to provide care for the family including diet management, foot care and exercises.

\section{REFERENCES}

Abin Muslihin, 2012, Family Nursing, Goysen Publishing, Yogyakarta.

Alaa, M., et al., Nurses' Role in Diabetic Foot Prevention and Care; a review, Journal of Diabetic and Metabolic Disorder, 11: 24, Availabel at jdmdonline.com/content/:1/1/24.

Almatsier S (2005); Diet Guide. Second edition, Gramedia, Jakarta.

Black, MJ \& Hawks, HJ, 2001, Medical Surgical Nursing: Clinical Management for Positive Outcomes, $7^{\text {th }}$ Edition, Elsevier SaundersSt. Louis.
List of exchange food ingredients, (2010), third edition, Faculty of Medicine UI, Jakarta.

M. Func Funnel (2011); National Standards for Diabetes Self-Management Education, Diabetes Care, volume 34.

Hartono A, (2006); Nutrition Therapy and Hospital Diet, Issue 2, EGC, Jakarta

Justin BE, Samuel D (2012); Preventing DM in Developing countries, Nature Review Endocrinology, Volume 8, Mac Millan.

Consensus Management and prevention of Type 2 DM in Indonesia, (2006), Endocrinology Collection, Jakarta.

Lionnie KW, Parchman M, (2004); Family Support and Diet Barriers Among Older Hispanics Adults With Type 2 Diabetes.

Nongnut, O, McCaffrey R, (2010); Development of a Community Participation program for Diabetes Mellitus Prevention in a Primary Care Unit, Nursing and Health Science, 13,352-359, Blackwelll Publishing Asia.

Nur Salam, 2013, Research Methods in Nursing, Issue 3, Salemba Medika, Jakarta.

Skinner ST, John M, (2000); Social Support and personal Models of a Diabetes as Predictors of self-care and well-being: A Longitudinal Study of Adolescents with Diabetes, Journal of Pediatrics Psychology, vol. 25, no. 4.pp.257-267.

Svartholm, S., \& Nylander, E., 2010, Self Care Activities of Patients with Diabetes Mellitus Type 2 in Ho Chi Minh City, Department of Public Health and Caring Science, Uppsala Universitet.

Wen LK, Shepherd MD (2012); Family Support, Diet and Exercise Amonf older Mexican Americans with Type 2 Diabetes. 
Teli, M. (2019). Family Empowerment Model for Type 2 DM Management: Integration of Self care Model by Orem and Family Centered Nursing by Friedman in Sikumana Health CenterKupang. JURNAL INFO KESEHATAN, 17(1), 75-87. https://doi.org/10.31965/infokes.Vol17.Iss1.261

Alligood, MR and Tomey, AM (2006). Nursing

Theoriests and Their Work.6th Ed. Missouri; Mosby.

Freeman, R. \& Heinrinch, J (1981).

Community Nursing Practice,

Philadelphia; WB. Sauders.
Friedman, MM, Bowden VR, \& Jones EG (2003). Family Nursing Research, Theory and Practice (5 ed). new Jersey: Practice Hall.

Ready to submit your research? Choose INFOKES and benefit from:

- fast, convenient online submission

- thorough peer review by experienced researchers in your field

- rapid publication on acceptance

- $\quad$ support for research data

- Open Access which fosters wider collaboration and increased citations

- maximum visibility for your research

At Health Polytechnic of Kupang, research is always in progress.

Learn more http://jurnal.poltekkekupang.ac.id/index.php/infokes 